\title{
ANALISIS KUALITAS RUMPUT LAUT Gracilaria gigas YANG DIBUDIDAYA PADA HABITAT LAUT DAN TAMBAK, NUSA TENGGARA BARAT
}

\author{
Farah Diana"), Kukuh Nirmala**), dan Dinar Tri Soelistyowati" \\ ") Universitas Teuku Umar \\ Jl. Kampus Alue Peunyareng Meulaboh, Aceh Barat 23615 \\ E-mail: farahdiana-d@yahoo.com \\ **) Institut Pertanian Bogor \\ Jl. Agatis, Kampus IPB Darmaga, Bogor 16680
}

(Naskah diterima: 28 Mei 2013; Disetujui publikasi: 6 Januari 2014)

\begin{abstract}
ABSTRAK
Gracilaria gigas merupakan tumbuhan tingkat rendah yang berasal dari laut dan umumnya dibudidaya di tambak. Pengembangan budidaya rumput laut di tambak bertujuan memperluas kawasan produksi dengan produktivitas yang tinggi, kualitas rumput laut dan agar yang berbeda dengan di laut. Budidaya Gracilaria gigas di tambak dilakukan di Sekotong, Lombok Barat, Nusa Tenggara Barat dengan menggunakan metode broadcast dengan luas area budidaya $1.500 \mathrm{~m}^{2}$. Sedangkan budidaya di laut dilakukan di Teluk Gerupuk, Lombok Tengah dengan metode long line dengan luas area budidaya $1.250 \mathrm{~m}^{2}$. Parameter yang diukur meliputi performa dan kualitas rumput laut, serta kualitas air. Parameter kualitas air yang diukur adalah: suhu, salinitas, $\mathrm{pH}, \mathrm{NO}_{3}-\mathrm{N}, \mathrm{NO}_{2}-\mathrm{N}, \mathrm{NH}_{3}-\mathrm{N}, \mathrm{PO}_{4}-\mathrm{P}$, dan kecerahan yang diambil pada hari ke-0, 10,20 , dan 30. Rata-rata produktivitas Gracilaria gigas di laut lebih tinggi 12,72\% daripada di tambak. Sebaliknya rendemen agar dan kekuatan gel Gracilaria gigas hasil budidaya di tambak hampir tiga kali lipat lebih tinggi daripada di laut dan berkorelasi positif dengan kandungan $\mathrm{N}$ perairan dan indeks percabangan. Kualitas rumput laut berhubungan erat dengan suhu, $\mathrm{DO}, \mathrm{PO}_{4}-\mathrm{P}$, dan $\mathrm{NH}_{3}-\mathrm{N}$ terlarut dalam air. Tingginya rendemen agar dan kekuatan gel di tambak disebabkan oleh banyaknya kandungan nutrien dan unsur hara, sedangkan tingginya produktivitas hasil budidaya Gracilaria gigas di laut disebabkan oleh adanya respons struktural dan tekanan turgor pada rumput laut.
\end{abstract}

KATA KUNCI: budidaya, kualitas, produktivitas, Gracilaria gigas

ABSTRACT: Seaweed quality analysis of Gracilaria gigas which cultivated in ponds and seashore habitats, West Nusa Tenggara. By: Farah Diana, Kukuh Nirmala, and Dinar Tri Soelistyowati

Seaweed Gracilaria gigas produces agarofit which is naturally found in the sea and commonly cultivated in ponds, the purpose of this study was to compare the quality of G. gigas which was cultivated in the pond and the sea. The cultivation of G. gigas in ponds was held in Sekotong, West Lombok by broadcast method in $1,500 \mathrm{~m}^{2}$ planting area. While cultivation in the sea was held in Gerupuk Bay, Central Lombok by long line method in the areas of $1,250 \mathrm{~m}^{2}$. The water quality parameters such as temperature, salinity, $\mathrm{pH}, \mathrm{NO}_{3}-\mathrm{N}, \mathrm{NO}_{2}-\mathrm{N}, \mathrm{NH}_{3}-\mathrm{N}, \mathrm{PO}_{4}-\mathrm{P}$, and transparency were measured on $-0,10$, 20 , and 30 day of culture. The average productivity of G. gigas in sea was $12.72 \%$ higher than that in the ponds. The rendemen of agar and gel strength of G. gigas that was cultivated in ponds almost reached 3 fold higher than those in the sea, and correlated positively with the amount of $N$ content in water and branching index. 
Quality of seaweed was highly correlated with temperature, $\mathrm{DO}, \mathrm{PO}_{4}^{-} \mathrm{P}$, and $\mathrm{NH}_{3}-\mathrm{N}$. High level of agar rendemen and gel strength in pond was influenced by the availability of nutrient in the pond while the productivity of G. gigas yield in the sea was influenced by the structural response and turgor pressure of the seaweed.

\section{KEYWORDS: seaweed cultivated, seaweed quality, productivity, Gracilaria gigas}

\section{PENDAHULUAN}

Rumput laut merupakan tumbuhan tingkat rendah yang secara morfologi terdiri atas talus (batang) yang bercabang-cabang (tanpa akar), dan hidup pada substrat di dasar laut dengan kedalaman yang masih dapat dicapai oleh cahaya matahari. Gracilaria merupakan salah satu spesies rumput laut yang sudah banyak dibudidayakan. Spesies ini diproduksi karena tergolong dalam kelompok rumput laut penghasil agar (agarofit). Salah satu keunggulan dari pigmen coklat pada Gracilaria gigas mampu menyerap intensitas cahaya matahari dalam kondisi kekeruhan tinggi (Durairatnam et al., 1990).

Menurut McHugh (2003), pada era awal industri agar di negara Chili, Gracilaria hanya diambil dan dikumpulkan dari alam untuk mendukung suplai Gelidium yang menjadi penghasil utama agar. Meningkatnya kebutuhan bahan baku industri tidak dapat dipenuhi oleh produksi spesies Gelidium. Oleh karena itu, teknik budidaya Gracilaria mulai dikembangkan baik di tambak maupun di laut. Teknik budidaya tersebut yang kemudian tersebar ke berbagai negara seperti Korea, Cina, Namibia, Filipina, Indonesia, dan Vietnam.

Teknologi budidaya Gracilaria yang telah berkembang di Indonesia tergolong masih sederhana. Bibit rumput laut ditanam dengan cara ditebar merata pada area tambak. Budidaya Gracilaria dilakukan baik secara monokultur, polikultur maupun dengan metode budidaya multitrofik terintegrasi bersama dengan komoditas budidaya lainnya, seperti ikan, udang, dan kekerangan (Xin, 1988).

Menurut Zatnika (1997), di Indonesia Gracilaria merupakan spesies utama yang dibudidayakan sebagai komoditas penghasil agar. Namun produksi Gracilaria dari hasil budidaya di tambak belum dapat memenuhi kebutuhan pasar. Salah satu upaya untuk meningkatkan produksi adalah dengan cara mengembangkan budidaya Gracilaria di laut. Selain untuk meningkatkan produksi, di- harapkan budidaya Gracilaria di laut dapat menghasilkan rumput laut yang lebih berkualitas. Terkait habitat asli dari rumput laut sendiri adalah di laut, maka penelitian ini dilakukan untuk mengkaji perbedaan performa budidaya rumput laut Gracilaria gigas di laut dan di tambak baik dari segi produktivitas, kualitas maupun kuantitas.

\section{BAHAN DAN METODE}

Bibit rumput laut yang digunakan dalam penelitian ini adalah jenis Gracilaria gigas dari Sekotong, Kabupaten Lombok Barat. Budidaya dilakukan di laut dan di tambak. Budidaya rumput laut di laut menggunakan metode long line dengan unit budidaya $25 \mathrm{~m} \times 50 \mathrm{~m}$, sedangkan budidaya di tambak dengan metode broadcast. Budidaya berlangsung selama satu siklus dengan masa pemeliharaan 30 hari sesuai kebiasaan masyarakat pembudidaya rumput laut di lokasi tersebut. Selama penelitian dilakukan pengujian terhadap sampel air laut dan tambak dari lokasi budidaya yang diambil pada hari ke-0, 10, 20, dan 30. Parameter uji yang diamati selama penelitian meliputi kualitas rumput laut (rendemen agar, Clean Anhydrous Weed (CAW), kadar air, serat kasar, dan kadar abu), agar (viskositas, kekuatan gel, derajat putih, titik jendal, titik leleh, dan kadar sulfat), produktivitas rumput laut Gracilaria gigas, indeks percabangan (branching index), jumlah talus sekunder (JTS), jumlah talus tersier (JTT), dan jumlah total talus (JT) rumput laut, serta kualitas perairan lokasi budidaya.

Seluruh data dianalisis menggunakan uji nilai tengah statistika deskriptif (t-test). Hubungan parameter kualitas air dan indeks percabangan dianalisis dengan menggunakan metode cluster analysis dan analisis komponen utama (principal component analysis).

\section{HASIL DAN BAHASAN}

\section{Performa Rumput Laut}

Produktivitas Gracilaria gigas yang dibudidaya di laut tiga kali lipat lebih tinggi 
$(12,72 \%)$ dibandingkan dengan yang budidaya di tambak (Gambar 1). Menurut Kadi \& Atmadja (1988), budidaya Gracilaria gigas di laut terjadi pembesaran sel akibat adanya tekanan pasang surut dan arus, dan menurut Dawes (1981), di laut terjadi respons struktural pada alga terhadap cahaya yang mengakibatkan perbedaan morfologi, reproduksi, fisiologi, dan sitoplasmik sehingga pertumbuhan memanjang dan sel membesar maka tekanan turgor di dalam sel akan mudah masuk dan menyebabkan talus sekunder yang dibudidayakan di laut juga lebih tinggi (36,20\%). Sedangkan di tambak pertumbuhan lebih ke arah reproduktif (membangun sel baru menjadi individu baru dengan memperbanyak sel generatif). Dawes et al. (1981) menyatakan budidaya rumput laut Gracilaria gigas pada kondisi lingkungan yang berbeda akan menghasilkan produktivitas yang berbeda.

Jumlah talus pada Gracilaria gigas yang dibudidaya di tambak tinggi $(86,56)$ dibandingkan dengan di laut $(80,40)$; demikian jumlah talus tersier $(54,07)$ dan indeks percabangan (18,38). Menurut Pickering et al. (1995), indeks percabangan erat kaitannya dengan ketersediaan nutrien dan unsur hara dalam pembentukan sel baru, di mana kandungan $\mathrm{N}$ di tambak lebih tinggi dibandingkan dengan di laut. Selain itu, jumlah talus tersier dua kali lipat lebih tinggi di tambak $(54,07)$ dibandingkan dengan di laut $(38,70)$; hal ini berhubungan erat dengan indeks percabangan.

\section{Kualitas Rumput Laut}

Kualitas rumput laut tidak hanya dipengaruhi oleh teknik budidaya, tetapi juga dipengaruhi oleh umur tanam dan kondisi perairan (McHugh, 2003). Rumput laut dikatakan bermutu jika rendemen agarnya tinggi. Rendemen agar pada Gracilaria gigas yang dibudidayakan di tambak hampir tiga kali lipat lebih tinggi (18,53\%) dibandingkan di laut (Gambar 2). Menurut FAO (1987), tinggi rendahnya rendemen agar dipengaruhi oleh spesies rumput laut, iklim, dan usia panen. Berdasarkan BSN (1998) rumput laut Gracilaria gigas dikatakan baik jika kandungan agarnya lebih dari 25\%. Agar merupakan polisakarida yang terakumulasi dalam dinding sel rumput laut penghasil agar yang dipengaruhi oleh musim (Armisen \& Galatas, 2000). Kualitas rumput laut menurun, bila kadar abu terlalu tinggi. Kadar abu yang dikatakan baik tidak melebihi dari $40 \%$ yang telah distandarkan oleh FAO, dan kadar air pada rumput laut tidak memengaruhi kualitas rumput laut. Kadar abu pada Gracilaria gigas laut lebih tinggi $(52,25 \%)$ dibandingkan dengan tambak (Gambar 2).

Tingginya kadar abu pada budidaya Gracilaria gigas di laut diduga karena kandungan mineral rumput laut yang tinggi dan masih adanya sisa-sisa karang atau pasir yang masih terbawa walaupun pencucian dan sortasi sudah dilakukan dengan sebaikbaiknya.

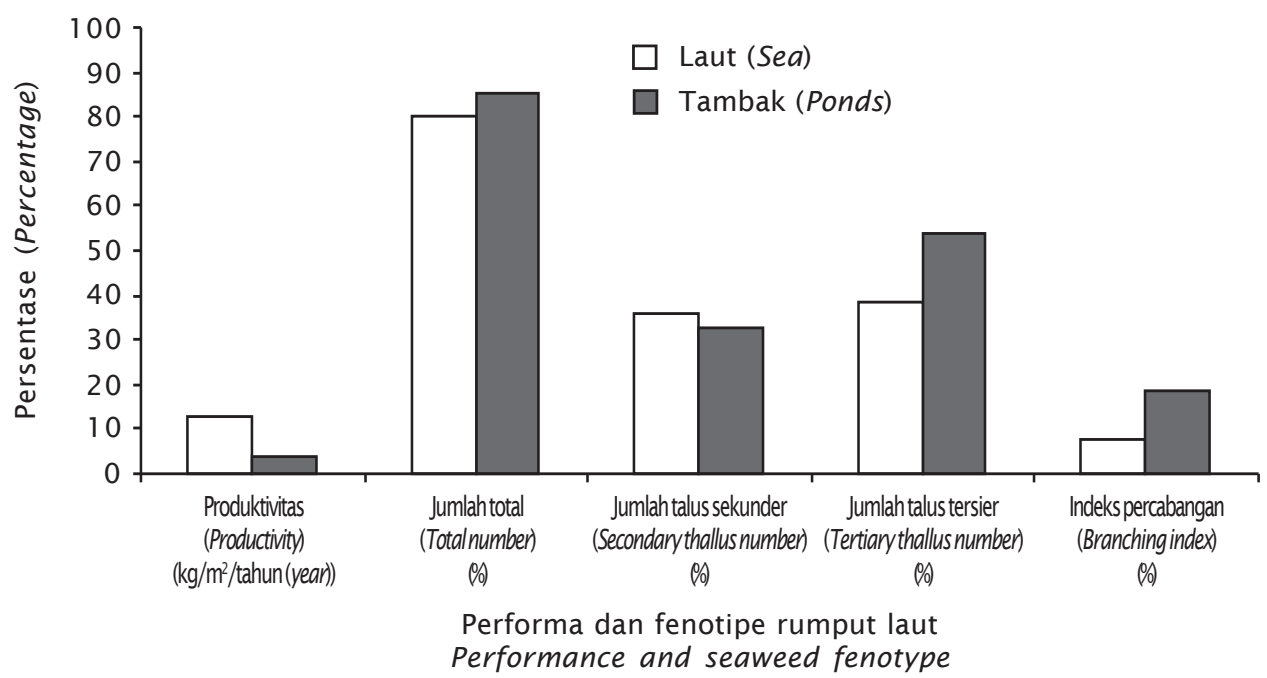

Gambar 1. Tingkat produktivitas dan indeks percabangan pada Gracilaria gigas

Figure 1. Productivity and branching index in Gracilaria gigas 


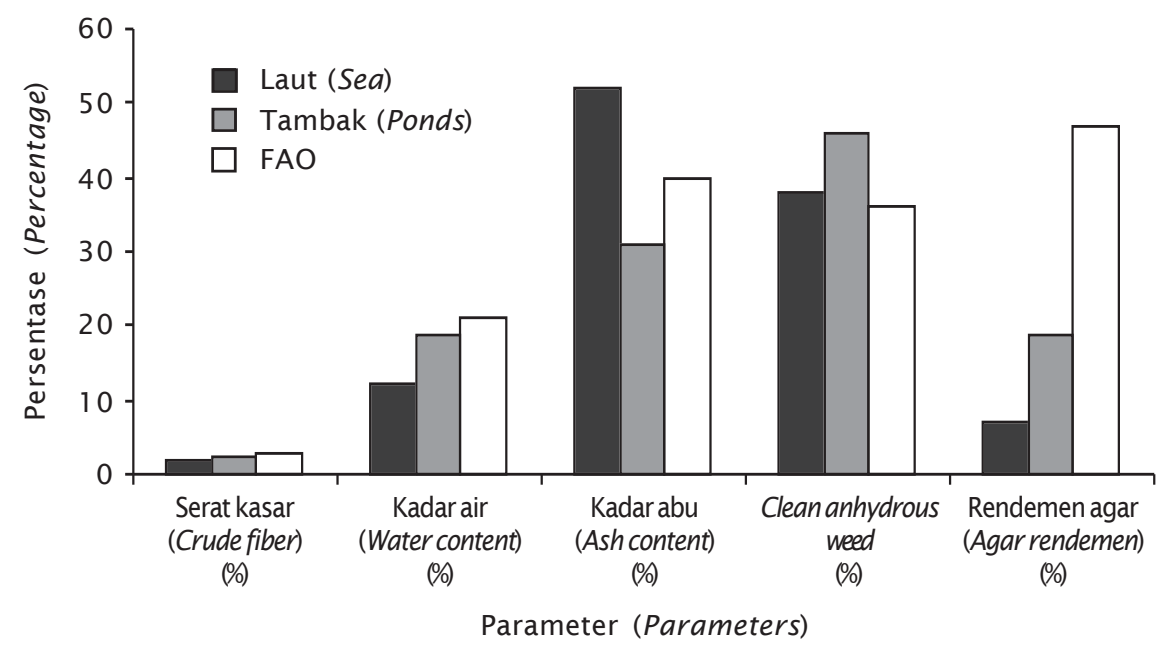

Gambar 2. Hasil analisis kualitas rumput laut

Figure 2. Result of seaweed analysis to determine quality

\section{Kualitas Agar}

Kualitas agar dipengaruhi oleh kandungan sulfat, apabila semakin tinggi, maka semakin rendah kualitas agarnya, yaitu mengurangi gel strength. Kandungan sulfat pada Gracilaria gigas yang dibudidaya di tambak mencapai $(5,18 \%)$ sedangkan di laut (4,95\%). Sedangkan standar yang ditetapkan oleh FAO, tidak melebihi dari 6\%. Menurut Murti (2007), senyawa sulfat dari garam-garam sulfat yang ada pada filtrat agar-agar yang belum terserap merupakan zat pengotor dalam agar. Kekuatan gel pada Gracilaria gigas hasil budidaya di tambak hampir tiga kali lipat lebih tinggi $(18,45)$ dibandingkan di laut (Gambar 3). Kandungan sulfat berhubungan erat dengan titik leleh dan titik jendal, semakin tinggi titik jendal, maka gel yang terbentuk semakin tinggi, dan semakin tinggi titik leleh, maka gel yang terbentuk rendah (Gambar 3).

Titik leleh tertinggi pada Gracilaria gigas yang dibudidaya di laut $\left(28^{\circ} \mathrm{C}\right)$ dan terendah pada tambak $\left(27^{\circ} \mathrm{C}\right)$, semakin tinggi bobot agar akan menghasilkan titik leleh yang tinggi dan semakin murni agar yang dihasilkan maka titik leleh gel semakin rendah (FAO, 1987). Viskositas berhubungan positif dengan konsentrasi agar. Menurut Towle (1973), viskositas dipengaruhi oleh konsentrasi larutan terlarut, suhu, dan molekul terlarut lainnya. Pada saat konsentrasi larutan meningkat, viskositas juga meningkat secara logaritmik.

\section{Hubungan Intervariabel Performa Rumput Laut dan Kualitas Air di Laut dan di Tambak}

Berdasarkan hasil analisis kemiripan sebaran parameter kualitas air dan performa rumput laut pada lokasi budidaya Gracilaria gigas di laut dan di tambak digambarkan pengelompokan variabel dengan tingkat kedekatan yang berbeda (Gambar 4). Pada cluster- 1 ditunjukkan bahwa $\mathrm{NO}_{3}-\mathrm{N}$ mempunyai hubungan erat dengan salinitas, $\mathrm{pH}$, dan kecerahan dengan indeks similaritas paling tinggi adalah 0,99. Dalam hal ini salinitas dan $\mathrm{NO}_{2}-\mathrm{N}$ memiliki hubungan yang saling memengaruhi $\mathrm{pH}$ dan kecerahan dengan indeks similaritas 0,96 . Sedangkan pada cluster-2 mewakili parameter suhu yang sangat erat kaitannya dengan indeks percabangan dengan indeks similaritas 0,92. Dalam hal ini suhu memiliki hubungan erat yang saling memengaruhi hingga mencapai 100\%. Pada cluster-3 mewakili parameter $\mathrm{NO}_{3}-\mathrm{N}$ yang berhubungan dengan $\mathrm{NH}_{3}-\mathrm{N}, \mathrm{JT}, \mathrm{PO}_{4}-\mathrm{P}$, dan $\mathrm{DO}$ dengan indeks similaritas 0,54 dan parameter nitrit memiliki hubungan dengan indeks percabangan pada indeks similaritas 0,43 (Gambar 4).

Tingkat keeratan hubungan antara indeks percabangan dengan variabel kualitas air di laut dan di tambak digambarkan pada Gambar 5. Variabel-variabel yang memiliki korelasi positif dengan indeks percabangan yaitu $\mathrm{PO}_{4}-\mathrm{P}$, 


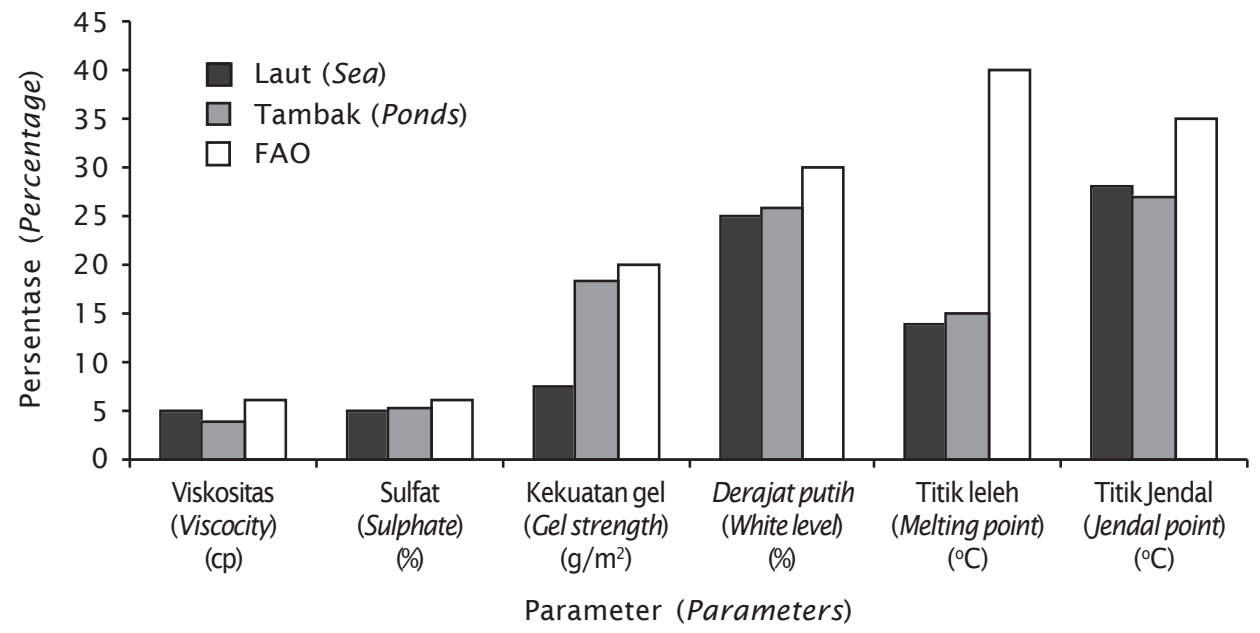

Gambar 3. Hasil analisis kualitas agar di laut dan di tambak

Figure 3. Result of jelly analysis quality cultured in the and sea and ponds

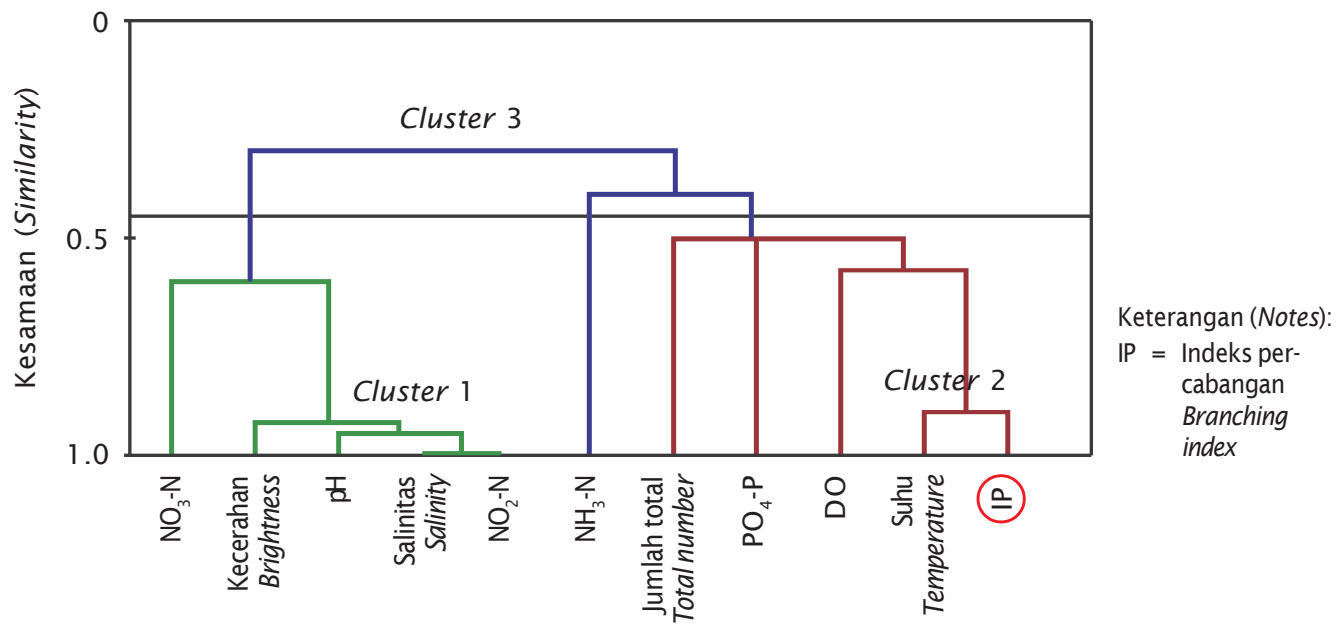

Gambar 4. Dendogram cluster dari parameter kualitas air di laut dan di tambak

Figure 4. Dendogram cluster of water quality parameter in sea and farm

$\mathrm{NH}_{3}-\mathrm{N}$, dan suhu perairan. Berdasarkan nilai koefisien korelasinya, ada dua variabel memiliki hubungan korelasi yang tinggi dengan indeks percabangan pada rumput laut yaitu suhu $(0,913)$ dan DO $(0,545)$.

Variabel yang berkorelasi negatif dengan indeks percabangan pada rumput laut yaitu kecerahan, $\mathrm{NO}_{3}-\mathrm{N}, \mathrm{NO}_{2}-\mathrm{N}, \mathrm{pH}$, dan salinitas (Gambar 6). Di antara variabel-variabel tersebut empat variabel memiliki nilai korelasi yang tinggi yaitu kecerahan $(-0,881), \mathrm{NO}_{2}-\mathrm{N}(-0,988)$, $\mathrm{pH}(-0,953)$, dan salinitas $(-0,996)$.
Pada sumbu utama variabel menjelaskan $59,21 \%(\mathrm{~F}-1)$ adalah salinitas, kecerahan, $\mathrm{NO}_{2}-$ $\mathrm{N}, \mathrm{NO}_{3}-\mathrm{N}$, dan $\mathrm{pH}$. Sedangkan variabel yang menjelaskan 21,34\% (F-2) adalah variabel suhu, $\mathrm{DO}, \mathrm{PO}_{4}-\mathrm{P}$, dan $\mathrm{NH}_{3}-\mathrm{N}$ dari informasi total hubungan performa rumput laut dan kualitas air.

\section{KESIMPULAN DAN SARAN}

\section{Kesimpulan}

Produktivitas Gracilaria gigas yang dibudidaya di laut lebih tinggi 12,72\% daripada di 


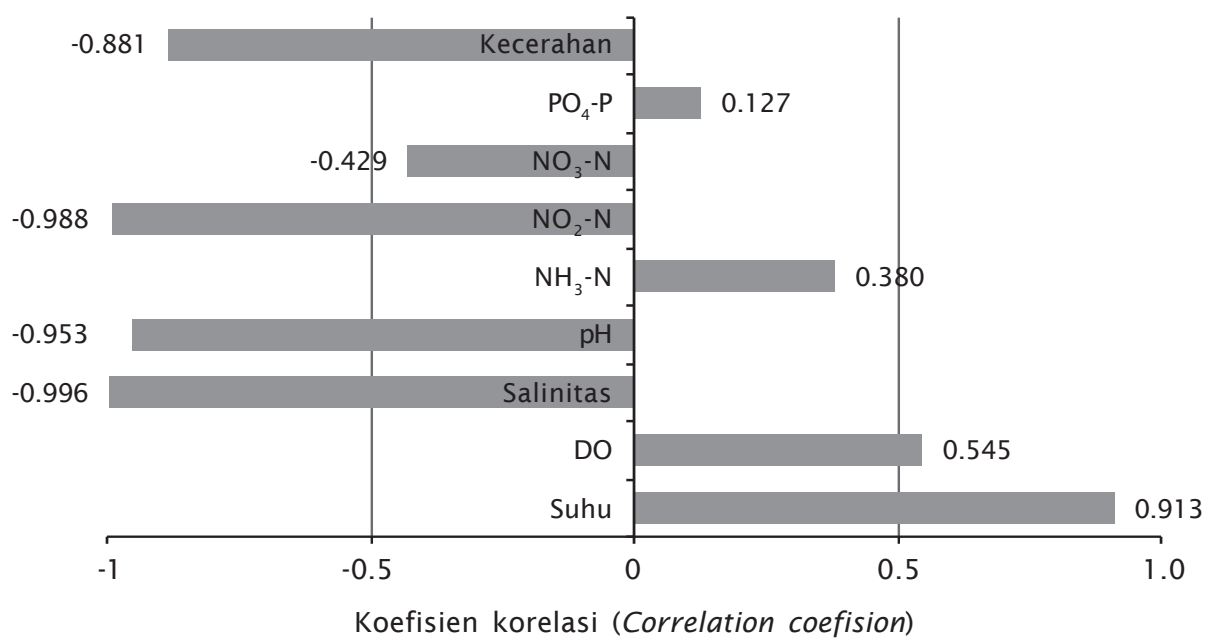

Gambar 5. Koefisien korelasi antara kualitas air dan indeks percabangan

Figure 5. Correlation coefision between water quality and branching index

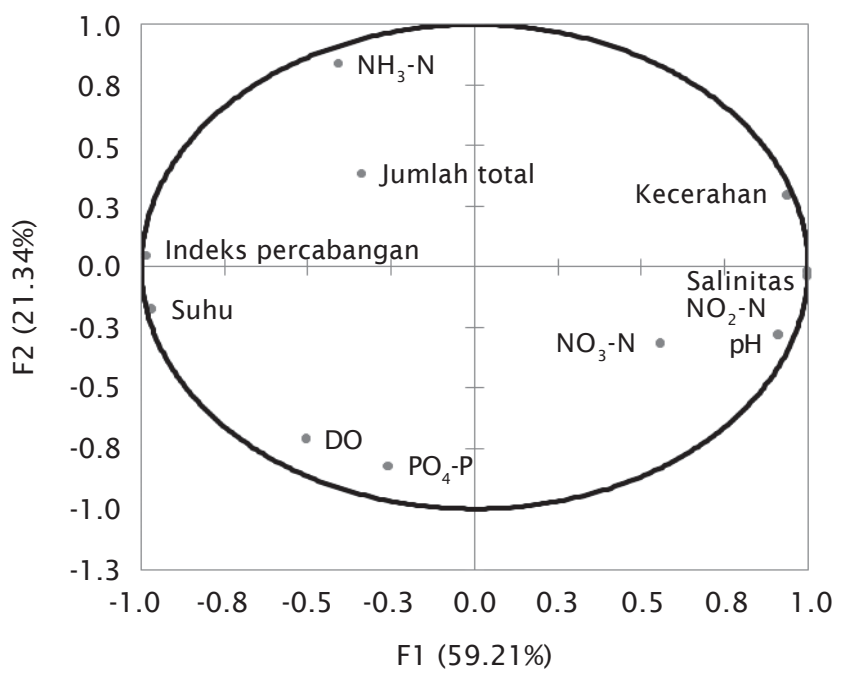

Gambar 6. Loading plot dari dua komponen utama pertama yang menjelaskan $80,56 \%$ dari keragaman total parameter yang diamati

Figure 6. Loading plot from two main component which explain $80.56 \%$ of diversity

tambak. Rendemen agar dan kekuatan gel Gracilaria gigas di tambak $(7,54)$ hampir tiga kali lipat lebih tinggi daripada di laut mencapai 18,46 dan berkorelasi positif dengan kandungan $\mathrm{N}$ dan indeks percabangan. Parameter kualitas air yang berkorelasi dengan kualitas rumput laut adalah suhu, $\mathrm{DO}, \mathrm{PO}_{4}-\mathrm{P}$, dan $\mathrm{NH}_{3}-\mathrm{N}$.

\section{Saran}

Perlu dilakukan perbaikan mutu bibit dan perluasan pengembangan kawasan budidaya Gracilaria gigas di tambak untuk meningkatkan produksi dan kualitas rumput laut, dan kualitas agar dan dapat diaplikasikan pada masyarakat atau petani rumput laut. 


\section{DAFTAR ACUAN}

Armisén, R. \& Galatas, F. 2000. Agar. In Phillips, G.O. \& Williams, P.A. (Eds.), Handbook of Hydrocolloids. England, Woodhead Publishing Limited.

Badan Standarisasi Nasional [BSN]. 1998. Standar Nasional Indonesia 01-2690-1998. Rumput Laut Kering. Dewan Standarisasi Nasional. Jakarta.

Dawes, C.J. 1981. Marine botany. John Wiley and Sons, Inc. Canada, 628 pp.

Durairatnam, M., de Brito Medeiros, T.M., \& de sena, A.M. 1990. Studies on the yield and gel strength of agar from Gracilaria domingensis Sonder ex Kuetzing (Gracilariales, Rhodophyta) following the addition of calcium. Proc. Int. Seaweed Symp., 13: 551553.

Food and Agriculture Organization of the United Station (FAO). 1987. The wild harvest and culture of the economically important species of gelidium in Chile. www. Fao.org. [4 November 2008].
Kadi, A. \& Atmadja, W.S. 1988. Rumput laut (Algae): jenis, reproduksi, produksi, budidaya dan pasca panen. Puslitbang Oseanografi. LIPI. Jakarta, $71 \mathrm{hlm}$.

McHugh, D.J. 2003. A guide to seaweed industry. FAO Fisheries Technical Paper No. 441. FAO. Rome, 105 pp.

Murti, A.W. 2007. A guide to the seaweed industry. www. Fao.org/seaweed. [3 Mei 2013).

Pickering, T.D., Gordon, M.E., \& Tong, L.J. 1995. A preliminary trial of a spray culture technique for growing the agarophyte Gracilaria chilensis (Gracilariales, Rhodophyta). Aquaculture, 13: 43-49.

Xin, C.J. 1988. Gracilaria culture in China. Network of aquaculture centres in Asian National Inland Fisheries Institute Kasetsart University Campus Bangkhen, Bangkok, Thailand.

Towle, A.G. 1973. Carrageenan. In Industri Gums. Whistler, R.L. (Ed.). New York Academic Press.

Zatnika, A. 1997. Profil industri rumput laut Indonesia. Tim Rumput Laut BPPT. BPPT. Jakarta. 